\title{
A FOSSIL PALM FRUIT FROM THE MIDDLE EOCENE OF NORTHWESTERN PERU
}

\author{
By Edward W. Berry \\ of Johns Hopkins University, Baltimore, Maryland
}

Calcified nuts of a palm are not uncommon at Negritos in northwestern Peru in the lower part of the Lobitos formation as delimited by Bosworth. ${ }^{1}$ The horizon, according to the collector, Dr. A. A. Olsson, is middle Eocene and about the same as the upper Claiborne of southeastern North America, that is to say, Auversian according to the European scale.

These nuts are somewhat larger than walnuts, mostly decorticated, and their interiors show no structural details. They appear to me to be referable to the genus Astrocaryum, and are named in recognition of the collector, who has done such excellent work in northwestern Peru. The types are deposited in the United States National Museum.

\section{ASTROCARYUM OLSSONI, new species}

Fruits as preserved varying in form from subspheroidal to prolate, more or less pointed distad and flattened proximad so that they are ovate in profile. They are usually widest at or below the middle, and full and rounded, or even truncate at the base. The upper half is always more or less narrowed and may be somewhat produced and pointed. Their dimensions range from 3.75 to $5.25 \mathrm{~cm}$. in length, and from 2.5 to 3.75 in maximum diameter. Despite the considerable variation in form and size they are believed to represent but a single species, since all of a dozen specimens are identical in surface markings.

The outer fibrous coat, which is preserved in patches on most of the speciments, is nowhere over $2 \mathrm{~mm}$. in thickness, although in no case is it certain that its original thickness has been calcified and preserved. It consists of stout longitudinal fibers. These can be seen over part of figure 2. The inner layer, which comprises the greater

\footnotetext{
${ }^{1}$ Bosworth, T. O., Geology of the Tertiary and Quaternary Periods in the Northwest Part of Peru. London, 1922.
} 
part of the surface in most of the speciments, is seen, in broken specimens, to be calcified for a thickness of between 2 and $3 \mathrm{~mm}$., and to be rather prominently and transversely reticulate rugose. The interior is filled with a structureless calcareous matrix and suggests that the nuts were single seeded.

The equatorial outline of these fruits is approximately circular, and they appear to have been practically symmetrical around the polar axis, although some speciments appear to indicate a slight distal curvature. The proximal end is usually broken or incrusted with matrix, but in one specimen (fig. 4) is seen to be perforated by a large excentrically located hole. None of the specimens are sufficient to show the presence or absence of the two other perforations so frequent in this tribe.

Cotypes.--Cat. No. 37194, U.S.N.M.

The relatively enormous thickness of the Tertiary in northwestern Peru west of the present Andes has led Bosworth ${ }^{2}$ to predicate not only the existence of the mountains in Eocene times as the source of the large amount of relatively coarse material that make up so much of these sediments, but also his belief that the climate at that time approached that of the present in this region in its aridity, a necessary correlary.

These abundant palm nuts offer some, though it must be confessed rather inconclusive evidence on this point. It is recognized that they might have been carried for considerable distances by either rivers or ocean currents. Astrocaryum fruits are not uncommon in the present sea drift on the Pacific coasts of Panama and Colombia, and if the currents were running in the right direction in the Eocene, as they do at the present time, these nuts could have been transported for considerable distances along the middle Eocene coast, and need not have grown in the immediate vicinity of where they are now found.

Possibly bearing upon this point are the results of certain unpublished studies by Dr. W. P. Woodring, which seem to indicate that the Tertiary Caribbean fauna did not cross the Isthmus of Panama or Central America to any appreciable extent when seaways were developed between the Atlantic and Pacific oceans because of the Pacific equatorial countercurrent and the greater tides of the Pacific in this region; and that the more tropical elements in the so-called Caribbean Tertiary faunas were of Pacific origin and indigenous on the west coast of tropical America.

The warm shore current that at the present time is an offset from the Pacific equatorial countercurrent, and which skirts the Colombian and Ecuadorian coasts, is known locally as El Niño. Its

${ }^{2}$ Bosworth, T. O., Geology of the Tertiary and Quaternary Periods in the Northwest Fart of Peru. London, 1922. 
more or less periodic increase in strength from unknown causes, as in February, 1925 when it brought floods to the semidesert coastal region of northwestern Peru, could doubtless carry such palm fruits as the present fossils southward, at least as far as Negritos, Peru, the locality where the fossils were collected. My son, E. Willard Berry, reports Entada and other drift fruits from the wet tropics to the north, as having reached Negritos this February (1926) during a somewhat less severe repetition of the climatic upset of 1925 .

Another alternative that may be mentioned is that the palms which furnished these fossil fruits grew inland and east of an Eocene mountain axis which was high enough to bring about conditions like those of the present time in this region, and that these fruits were transported to their final resting place by rivers which crossed this divide, which is negatived by the abundance of these fossil fruits. Granting the altogether unlikely presence of such a river, it would hardly be expected to deposit numerous individuals of a single species at one spot, unless perhaps their floating powers and the action of the waves or some combination of eddies or currents in the estuary or at the place of debouchure of such a river might be regarded as a selective agency. It seems to me that such a combination of events is so remote as to rule out this supposition altogether.

The third alternative is that these fossil fruits were from trees growing in the vicinity where they were fossilized. Personally I can not see the evidence for a great mountain axis in Eocene times making a semidesert of coastal Peru, and I believe, that, irrespective of the exact character of the Atlantic-Pacific divide in the earlier Tertiary, it was not sufficiently elevated to prevent the Pacific coast from receiving a greater rainfall than it receives at the present time, as is proven to have been the case during the lower Miocene. ${ }^{3}$

If the present species of Astrocaryum could be proven to have grown in the neighborhood of where its fruits were found fossil it would prove the humidity of the middle Eocene climate of coastal Peru. As it is the only described terrestrial plant known from this horizon in this region, it can not be considered to have any decisive weight. I am inclined to interpret its ecological message as indicating such a humid environment. This inclination is not due to my belief in the late Tertiary elevation of the Andes, but rests on the presence of a considerable flora in the Oligocene of that region. This Oligocene flora is made up of the silicified fruits and seeds of nearly a score of species, many of which could not withstand water transportation and hence must have grown near where they occur as fossils. These Oligocene plants indicate a climate with a rainfall

${ }^{3}$ Berry, Edward W., Proc. U. S. Nat. Mus., vol. 55, pp. 279-294, 1919. 
and consequently a vegetation normal to the latitude, and not such as has existed since the Andes were elevated. This Oligocene flora has not yet been described in print because of the great difficulty in making precise identifications of some of its members.

It seems scarcely possible that there should have been high mountains and a desert in their rain shadow during the middle Eocene when the border lands of Colombia, Ecuador, and Panama were submerged by the first transgression of the Tertiary sea, at a time when seaways were formed between the two oceans, and the sediments of which contain a common fauna. This is especially difficult to envisage because in the continuous series of deposits in northwestern Peru we find the Eocene passing into the Oligocene without any apparent structural break or faunal hiatus, and the indicated climate of the latter is moist and precludes high mountains.

I am indebted to O. F. Cook, our well known authority on living palms, for having examined these fossil fruits, and he is inclined to think that both the genera Attalea and Astrocaryum are represented. This may well be the case, but I can not see any generic differences among the 12 specimens which I have studied, and which I have accordingly referred to the second of these genera, to which the relationship seems the more conclusive.

Both genera include stemless to tall feather palms, with numerous species confined to America. Astrocaryum Meyer has about 30 existing species, ranging from southern Mexico to eastern Peru, and reaching their maximum in the rain forests of the Amazon basin, but also found in the Brazilian Campos. Although not a coastal type, rivers contribute its fruits to ocean currents and its empty fruits are recorded in the beach drift of both coasts of tropical America and the Azores by Guppy. The genus Attalea Humboldt, Bonpland, and Kunth contains about 25 existing species, ranging from Honduras to Colombia and southern Brazil, and along the eastern Andes to the Yungas of Boliva. Its fruits have not been recorded in the beach drift so far as I have been able to ascertain.

\section{EXPLANATION OF PLATE}

Figs. 1-4.-Astrocaryum olssoni Berry. From Eocene of Negritos, Peru.

1, 2. Side view of a large and small nut, figure 2 shows the outer longitudinal fibers in the middle region.

3. Side view of a more spherical nut showing the inner, transversely rugose surface.

4. Proximal view of a nut showing perforation. 


\section{$2 \mathrm{BHL}$ Biodiversity Heritage Library}

Berry, Edward Wilber. 1926. "A fossil palm fruit from the middle Eocene of northwestern Peru." Proceedings of the United States National Museum 70(2652), 1-4. https://doi.org/10.5479/si.00963801.70-2652.1.

View This Item Online: https://www.biodiversitylibrary.org/item/53444

DOI: https://doi.org/10.5479/si.00963801.70-2652.1

Permalink: https://www.biodiversitylibrary.org/partpdf/52002

\section{Holding Institution}

Smithsonian Libraries

\section{Sponsored by}

Smithsonian

\section{Copyright \& Reuse}

Copyright Status: Public domain. The BHL considers that this work is no longer under copyright protection.

This document was created from content at the Biodiversity Heritage Library, the world's largest open access digital library for biodiversity literature and archives. Visit BHL at https://www.biodiversitylibrary.org. 